\title{
Water Consumption by Hydropower, Does It Worth Allocation under Ethiopian Context
}

\author{
Mebruk Mohammed Nurhusein \\ Addis Ababa Institute of Technology, Addis Ababa, Ethiopia \\ Email:mebruk.mohammed@aait.edu.et,mima_moh@yahoo.com
}

How to cite this paper: Nurhusein, M.M. (2020) Water Consumption by Hydropower, Does It Worth Allocation under Ethiopian Context. Journal of Water Resource and Protection, 12, 183-202. https://doi.org/10.4236/jwarp.2020.123012

Received: January 22, 2020

Accepted: March 2, 2020

Published: March 5, 2020

Copyright $\odot 2020$ by author(s) and Scientific Research Publishing Inc. This work is licensed under the Creative Commons Attribution International License (CC BY 4.0).

http://creativecommons.org/licenses/by/4.0/ (c) (i) Open Access

\begin{abstract}
The Ethiopian water policy strictly follows water allocation as a principle in setting out water consumption problems and demand projection. Hydroelectric power plants supply the larger share $(88 \%)$ of the electricity in Ethiopia. $86 \%$ of Ethiopia's plan to 2020 energy supply is expected to be from hydropower. This paper defines water consumption in hydropower production as the quantity of water that leaves the analyzed projects (reservoir regulated hydropower projects) through evaporation. Water consumed by hydropower development has never been studied at a country scale. Thus, in attempting to understand water consumption by the hydropower development, this study will be the first to acknowledge the water consumption by all storage regulated hydropower plants developed in Ethiopia. While studying and designing reservoir regulated hydropower production, the overall effect of water consumption by the projects is assumed to be minimal; thus ignoring water allocation to hydropower projects is a common procedure in Ethiopia. In this study, for multipurpose projects, to identify the water consumption by hydropower against the other purpose (irrigation) consumption, water consumption factors based on economic benefits were used. The study has shown that the 14 existing and under construction reservoir regulated hydropower projects will consume 1.881 billion $\mathrm{m}^{3}$ of water annually. This will make hydropower the second most water consuming water resource development next to Irrigation in the country. Together with the 22 upcoming projects the water consumption will be 3.756 billion $\mathrm{m}^{3} / \mathrm{year}$. The results also show that hydropower consumption in the country will take an average of $2.41 \%$ of the total water stored in a reservoir. This value is in the range of nearly zero for power projects that use natural lakes as their reservoir (Tana Beles, Tis Abay I \& II) and GERD to $10.64 \%$. The total reservoir volume that will be created in the country after completion of the 22 planned projects is larger than 233 $\mathrm{BCM}$, which is greater than the surface water volume the country possesses. This indicates that the future water consumption by hydropower plants shall
\end{abstract}


be revised in accordance with changes made in the final design of each planned projects. Nonetheless, this research provides scientific support for the argument that the production of hydroelectricity by reservoir regulated hydropower schemes, in countries like Ethiopia, is a water consumer. Thus, water allocation shall not ignore its demand.

\section{Keywords}

Ethiopia, Reservoir Regulated Hydropower Projects, Water allocation, Water Consumption

\section{Introduction}

The Government of Ethiopia has put forward, 25-year national energy master plan, in 2005. In masterplan, hydropower is identified as the backbone in Ethiopia's national energy development strategy. Besides, a five-year plan called the Universal Rural Electrification Access Program (UREAP) has been included in this 25 -year master plan. The UREAP's goal is to increase access to electricity to $50 \%$ of the population.

Currently, Ethiopian Electric Power (EEP) administers 18 power plants, thereby generating a total of 4244-megawatt (MW) electricity nationwide. Most of the electric power in the nation is supplied from the inter-connected system (ICS). The ICS is fed predominantly by 14 major hydroelectric plants with a total installed capacity of 3814MW electricity: Aba Samuel (6.6 MW), Amerti Neshi (97 MW), Awash II (32 MW), Awash III (32 MW), Beles (460 MW), Fincha (134 MW), Gilgel Gibe I (184 MW), Gilgel Gibe II (420 MW), Gilgel Gibe III (1870 MW), Koka (43.2 MW), Melka Wakena (153 MW), Tekeze (300 MW), Tis Abay I (14.4 MW), and Tis Abay II (73 MW). Hydropower accounts for nearly $90 \%$ of the total public installed capacity, the remaining $10 \%$ being made up of several wind, geothermal and diesel projects [1].

$86 \%$ of Ethiopia's plan to 2020 energy supply is expected to be from hydropower [2]. The lack of diversity in Ethiopia's energy portfolio leaves the sector vulnerable to the water sector policy the country currently follows unless proper allocation of water is given to the sector. While studying and designing reservoir regulated hydropower production, the overall effect of water consumption by the projects is assumed to be minimal; thus ignoring water allocation to hydropower projects is a common procedure in Ethiopia. Currently, up to this research knowledge, no studies had been conducted to review Ethiopia's allocation-based policy which could negatively affect hydropower production. Besides, the water consumed by the existing hydropower developments has never been studied at a national scale.

Despite having higher water dependent than other power generation ways, hydropower water consumption receives relatively little attention in Ethiopia. 
The reason for this lack of attention may be the perception of reservoirs as suppliers of water rather than consumers. However, in country where water allocation is the core issue in its policy, construction of reservoirs may decrease regional water availability. Given the large number of planned projects in the country and the corresponding large quantities of water involved, a detailed investigation of the impact of allocation-based policy on hydropower generation is warranted. In attempting to understand the effect of water resources management policy on hydropower development, this study aims at evaluating the water consumption by all existing, under construction and planned storage regulated hydropower plants in Ethiopia and describe the impact on its production. Thus, this research will estimate the water consumed by storage regulated hydropower developments on the basis of the available data and information. The outputs from such analysis are then basically the annual water consumption by built, under construction and planned storage regulated hydropower projects. It is evident that the results' accuracy will vary depending on preceding levels of knowledge about the reservoir operation of the hydropower project.

Hydropower schemes generally classified as conventional type (runoff the river type, diversion and canal developments and storage regulated developments) and pumped storage type (Pure pumped storage type and Pumped and natural flow storage type). Among these developments the runoff the river developments can't have water loss as these developments use the "live" energy of the flowing river which won't create an anthropogenic water consumption. The diversion and canal developments will create water consumption. By comparing the natural water loss (if the water was in its natural course) against the new canal system that carries the river water away from its natural course, the water consumption by such projects can be computed. The storage regulated developments create water loss due to the fact that evaporation occur over a larger surface area (created by the impoundment) than the natural river course. Storage of water behind large hydropower dams leads to consumptive water use through evaporation from the open water surface of the artificial lake. That is why a number of studies ([3]-[11]) suggest the water consumption by reservoir regulated hydropower projects is larger and shall not be overlooked.

Evaporation estimation for specific reservoirs that generate hydropower was the main approach. Few efforts of quantifying evaporation loss from hydropower projects at regional scale were seen in literature ([3] [6]). For reservoirs used to produce hydroelectric power in the USA, reference [6] used aggregation of individual average yearly pan evaporation data to come up with a nationwide evaporation. Anthropogenic reasons to increase the evaporation were not incorporated in this gross reservoir evaporation approach. Hence the result does not represent the real evaporation as it does not account for the background evapotranspiration from the land surface prior to dam construction.

Reference [11] identified issues that include lack of water loss attributed to different uses for multipurpose reservoirs, inconsistent system boundaries and 
integration of water consumption in natural water bodies for the crudeness of the gross evaporation approach. Reference [11] suggested subtracting the background evapotranspiration rate from the gross reservoir evaporation rate to appropriately account for the anthropogenic influence of the hydropower project.

Ethiopia is fast becoming a center of industry and new infrastructure, with the aspiration to achieve middle income status by 2025. Since 2011, Ethiopia has implemented the Climate-Resilient Green Economy (CRGE) strategy, which substitutes conventional development by means of harnessing clean energy sources like hydropower, wind, geothermal, solar and biomass, and implementing energy-efficient technologies in the transport and industrial sectors [12].

Ethiopia is cited as having the second highest potential for hydro capacity in Africa (45,000 MW) and over 300 sites have reportedly been identified for possible future development [13]. The government of Ethiopia is embarking on a program of new electricity-sector developments. The current energy plan is limited almost entirely to developing large hydropower dams, including a power surplus for export [14].

The country has already planned and achieved the construction of several hydro-power facilities (Table 1). Plants constructed in the last ten years include Tekeze (completed in 2009), Tana Beles (completed in 2010), Gilgel Gibe II (completed in 2010), Gilgel Gibe III (completed 2017). Three major dams are currently under construction: Genale Dawa-3, Koysha Dam and Grand Ethiopian Renaissance Dam (GERD) (6400 MW, to start full production in 2022). With all these developments the water consumption by hydropower is expected to become larger and larger in upcoming years.

\section{Methodology}

\subsection{Water Consumption Analysis}

In the World Congress organized by the International Hydropower Association, 14-17 June 2011 in Brazil, a special session was devoted to the question: does hydropower consume water? The session explored different interpretations of water "consumption" in an attempt to recognize the energy impacts on water [16]. According to the Water Footprint Manual [17], "consumption" refers to loss of water from the available ground- and surface water body in a catchment area. Losses occur when water evaporates from the surface of water bodies and leaves the analyzed domain. This paper defines water consumption, in hydropower production, as the quantity of water that leaves reservoir regulated single purpose or multipurpose hydropower projects through evaporation. Thus, in this study first, the average yearly evaporation across the country will be estimated. Next, the water consumption of hydropower based on the annual evaporation rate at its location and the surface area of the reservoir will be calculated.

The water consumption analysis due to evaporation from reservoirs created for hydroelectric dams (functional, under construction and planned) in Ethiopia is summarized in Figure 1. 
Table 1. Storage regulated hydropower development status in Ethiopia (source [1] [15]).

\begin{tabular}{|c|c|c|c|c|c|c|c|}
\hline No. & Name & River Basin & $\begin{array}{c}\text { Installed } \\
\text { Capacity } \\
(\mathrm{MW})\end{array}$ & No. & Name & River Basin & $\begin{array}{c}\text { Installed } \\
\text { Capacity } \\
(\mathrm{MW})\end{array}$ \\
\hline \multicolumn{8}{|c|}{ a. Operational } \\
\hline 1 & Aba Samuel & Awash & 6.6 & 7 & Melkawakena & Wabe Shebele & 153 \\
\hline 2 & Amerti Neshe & Abay & 97 & 8 & Tana Beles & Abay & 460 \\
\hline 3 & Fincha & Abay & 134 & 9 & Tekeze-1 & Tekaze & 300 \\
\hline 4 & Gibe-III & Omo Gibe & 1870 & 10 & Tis-Abay-I & Abay & 12 \\
\hline 5 & Gilgel Gibe I & Omo Gibe & 183.9 & 11 & Tis-Abay-II & Abay & 73 \\
\hline 6 & Koka & Awash & 43.2 & & Total Functional & & 3332.7 \\
\hline \multicolumn{8}{|c|}{ b. Under Construction } \\
\hline 1 & Genale Dawa-3 & Genale Dawa & 254 & 3 & Koysha & Omo Gibe & 2160 \\
\hline 2 & GERD & Abay & 6450 & & Total Under Constru & & 8864 \\
\hline \multicolumn{8}{|c|}{ c. Feasibility } \\
\hline 1 & TAMS & Baro Akobo & 2000 & 7 & Genale Dawa-6 & Genale Dawa & 246 \\
\hline 2 & Baro-1 & Baro Akobo & 180 & 8 & Gojeb & Omo Gibe & 153 \\
\hline 3 & Baro-2 & Baro Akobo & 500 & 9 & Hallele Werabesa I & Omo Gibe & 96 \\
\hline 4 & Chemoga-Yada & Abay & 162 & 10 & Hallele Werabesa II & Omo Gibe & 326 \\
\hline 5 & Geba I & Baro Akobo & 180 & & & & \\
\hline 6 & Geba II & Baro Akobo & 157 & & Total Feasibility & & 3700 \\
\hline \multicolumn{8}{|c|}{ d. Other Planned (pre-feasibility, reconnaissance or identification stage) } \\
\hline 1 & Beko-Abo & Abay & 935 & 8 & Upper Dabus & Abay & 326.28 \\
\hline 2 & Karadobi & Abay & 1600 & 9 & Lower Dedessa & Abay & 550 \\
\hline 3 & Wabeshebele-18 & Wabe Shebele & 87.5 & 10 & Lower Dabus & Abay & 250 \\
\hline 4 & Beshilo & Abay & 700 & 11 & Birbir A & Baro Akobo & 97.4 \\
\hline 5 & Tekeze-2 & Tekeze & 450 & 12 & Birbir-R & Baro Akobo & 467 \\
\hline 6 & Gibe- 4 & Omo Gibe & 1472 & & & & \\
\hline 7 & Gibe 5 & Omo Gibe & 660 & \multicolumn{3}{|c|}{ Total Other Planned } & 7709.15 \\
\hline
\end{tabular}

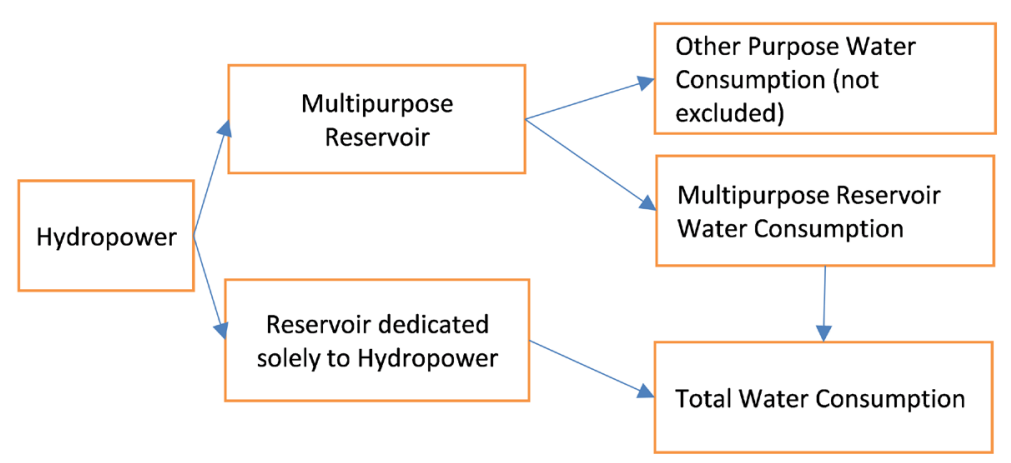

Figure 1. Hydropower water consumption calculation approach. 
Two different sets of equations are commonly used for water consumption by reservoirs viz. gross water consumption and net water consumption. It should be noted that the given water consumption estimates (as in Equations (1) and (2)) are specific water consumption rates, expressed per unit of energy production, and not absolute water consumption. The specific water consumption estimates must be multiplied by the energy production in order to indicate how much water is "lost" to the atmosphere due to evaporation.

$$
\begin{aligned}
& \text { Gross Water Consumption }=\frac{\text { Resevoir Evaporation }}{\text { Annual Energy Production }} \\
& \text { Net Water Consumption } \\
& =\frac{\text { Resevoir Evaporation }- \text { Evaporation Before Inundation }}{\text { Annual Energy Production }}
\end{aligned}
$$

In Ethiopia the published estimates of water consumption from hydropower plants use the gross water consumption equation (viz. [18] [19] [20] and [21]). This approach does not take into account the evaporation losses prior to construction of the hydropower project. The reservoir could originally be a natural lake or terrestrial area inundated due to the establishment of the reservoir, which need some consideration in the gross water consumption. The "net" calculation method (Equation (2)) however, subtracts evaporation rates from the reservoir surface by the evaporation rates prior to the hydropower development. The "net" method, somehow needs estimation of these prior water consumptions.

\subsection{Evaporation Estimation}

A number of methods for the estimation of evaporation exist in literature. These methods can be grouped into several categories (Singh and Xu, 1997): (i) empirical, (ii) water budget, (iii) energy budget, (iv) mass transfer and (v) a combination of these methods. Empirical methods relate pan evaporation, actual lake evaporation or lysimeter measurements to meteorological factors using regression analyses. Empirical methods have limited range of applicability. The water budget methods are simple and can potentially provide a more reliable estimate of evaporation, as long as each water budget component is accurately measured. However, owing to difficulties in measuring some of the variables such as the seepage rate in a water system the water budget methods rarely produce reliable results in practice ([22] [23]). In the energy budget method, the evaporation from a water body is estimated as the difference between energy inputs and outputs measured at a site. Energy budget methods are considered to be the most reliable in theory ([22] [23]), but require costly instrumentation and a large commitment of personnel for field work and data processing [24]. The mass-transfer (aerodynamic) based methods utilize the concept of eddy motion transfer of water vapor from an evaporating surface to the atmosphere. The mass-transfer methods normally use easily measurable variables and give satisfactory results in many cases. However, measurement of wind speed and air temperature at inconsistent heights, have resulted in a large number of equations 
with similar or identical structure [23]. The combination methods combine the mass transfer and energy budget principles in a single equation. Two of the most commonly known combination methods are the Penman equation and the Penman-Monteith equation. The Penman-Monteith equation is an empirical approach which can be applied for different water bodies wherein heat storage within the water bodies is considered. Therefore, evaporation estimation for the selected storage regulated hydropower projects was analyzed using the Penman-Monteith equation.

The evaporation from the water surface $(E d, \mathrm{~mm} /$ year) can be estimated using the Penman-Monteith equation with an inclusion of water body heat storage. The evaporation of each reservoir was calculated by using the following equation [25]:

$$
E T c=K c \times E T o
$$

where: $E T c=$ Crop evapotranspiration in depth $(\mathrm{mm} / \mathrm{year}), K c=$ Crop coefficient $(-), E T o=$ Reference evapotranspiration (mm/year)

Regarding the use of ETo and $K c$ to estimate evaporation, has been derived from [25], where the $K c$ values for open water less than $2 \mathrm{~m}$ depth or in sub humid climates or tropics (where Ethiopia resides) expected to have $K c$, of 1.05 . For open water $K c=1.00$ is used, for which the evaporation would be underestimated by $5 \%$ for the shallow portion of reservoirs [26]. The above equation is then simplified to:

$$
E T C=E T o
$$

Considering that there is no transpiration element to this analysis, the above equation becomes:

$$
E d=E T o
$$

where:

$E d=$ Reservoir evaporation (mm/year)

$E T o=$ Reference evapotranspiration (mm/year)

In volumetric units: $E V=E T o \times A \times 10^{-6}$

where:

$E_{V}=$ Reservoir evaporation in billions of $\mathrm{m}^{3} /$ year (BMC/Year)

$E T o=$ Reference evapotranspiration in depth (specific to each dam) (mm/year)

$A=$ Reservoir surface area (specific to each dam) in square kilometers $\left(\mathrm{Km}^{2}\right)$

On the basis of 931 met stations found in Ethiopia Penman-Monteith method as described in [25] was used for ETo computation. In light of this ETo map shown in Figure 2 was obtained. The use of the above equation in this study, where $K c=1.0$, would introduce an error of $5 \%$. The evaporation in volume was calculated for each dam by multiplying the surface area of each dam's reservoir by the $E d$ for its geographic area.

\section{Data Important for Evaporation Estimation}

Data pertinent to water consumption by hydropower as discussed above can be classified as meteorology and reservoir related data. The meteorological data 


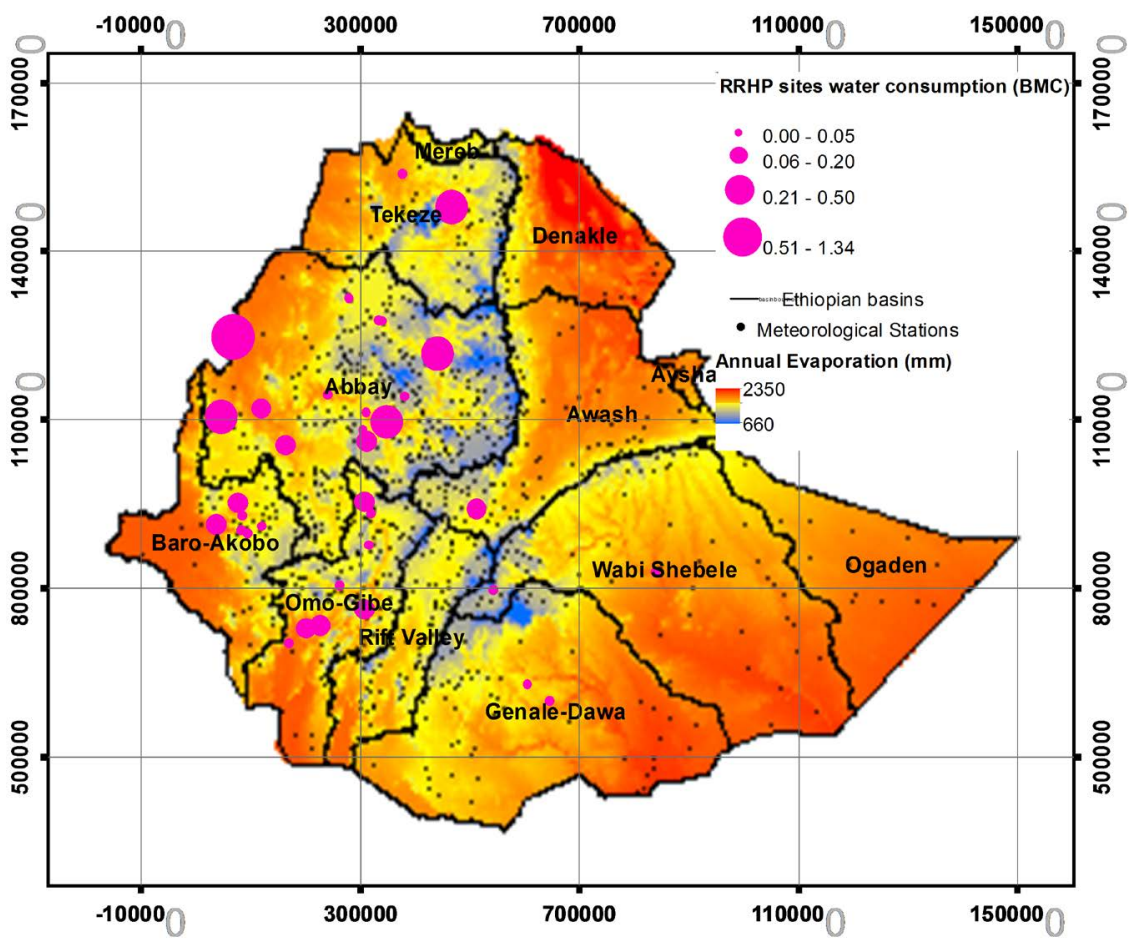

Figure 2. Hydropower reservoir location and the annual ETo across Ethiopia.

include, annual rainfall $(R F)$ and Annual Evaporation and/or reference evapotranspiration $(E T o)$. The reservoir related data include Highest Reservoir Level $(H R L)$, Lowest Reservoir Level ( $L R L)$, Total Storage (TS), Live Storage (LS), Reservoir surface area at $H R L(R S A)$, Reservoir extension upstream of the dam axis $(R E x t)$, real time reservoir rule curves and area capacity curves. However, these data were not obtained in full detail, especially the real time reservoir operation curves of the reservoir regulated hydropower (see Table 2).

As shown in Table 2, 31 of the 37 hydropower reservoirs have data on capacity; of those, 22 dams have data on full reservoir level surface areas. Considering the omissions on area capacity curve and reservoir rule curves, the surface area information relevant for evaporation estimation had to be filled. The missing reservoir surface areas were much more complicated to fill, given the vast variety of dam shapes and sizes. The following methodology, developed by GRanD (Global Reservoirs and Dams database) was attempted to fill the missing reservoir surface area estimation [26]:

$$
\begin{aligned}
& V=0.678(A H)^{0.9229} \\
& V=30.684(A)^{0.9578}
\end{aligned}
$$

where:

$V=$ Reservoir volume $\left(10^{6} \mathrm{~m}^{3}\right), A=$ Reservoir area $\left(\mathrm{Km}^{2}\right)$ and $H=$ Dam height (m)

These equations were developed by GRanD to estimate missing reservoir volumes, if both area and dam height were available, or if only the reservoir area 
Table 2. Data collected on reservoir characters related to water consumption.

\begin{tabular}{|c|c|c|c|c|c|c|c|c|c|}
\hline No. & Name & $R F,(\mathrm{~mm} / \mathrm{yr})$ & $\begin{array}{c}\text { ETo, } \\
(\mathrm{mm} / \mathrm{yr})\end{array}$ & $\begin{array}{c}H R L, \\
(\mathrm{~m} \text { amsl) }\end{array}$ & $\begin{array}{c}L R L \\
(\mathrm{~m} \text { amsl) }\end{array}$ & $T S,\left(10^{6} \mathrm{~m}^{3}\right)$ & $\begin{array}{c}L S \\
\left(10^{6} \mathrm{~m}^{3}\right)\end{array}$ & $\begin{array}{c}R S A \\
\left(\mathrm{~km}^{2}\right)\end{array}$ & $\begin{array}{l}R E x t \\
(\mathrm{~km})\end{array}$ \\
\hline 1 & Aba Samuel & - & - & 2050.0 & 2028.0 & 65.0 & - & - & 8 \\
\hline 2 & Amerti Neshe & - & - & 2234.0 & 2232.0 & 105.9 & 40.1 & 22.8 & - \\
\hline 3 & Fincha & - & - & 2219.0 & 2214.0 & 1120.5 & 1050.5 & 345.0 & - \\
\hline 4 & Gibe-III & 1426.0 & - & 892.0 & 649.0 & 14700.0 & 11750.0 & 200.0 & 155 \\
\hline 5 & Gilgel Gibe I & - & - & 1671.0 & 1658.3 & 840.0 & 513.1 & 51.1 & - \\
\hline 6 & Koka & - & - & 1590.7 & 1580.7 & 1186.2 & 1186.2 & 177.0 & - \\
\hline 7 & Melkawakena & - & - & 2520.7 & 2508.0 & 693.2 & 560.3 & 81.5 & - \\
\hline 8 & Tana Beles & 1450.0 & - & 1786.0 & 1784.0 & 32273.0 & 9126.0 & 3120.0 & - \\
\hline 9 & Tekeze-1 & 850.0 & - & 1140.0 & 1096.0 & 9293.0 & 5293.0 & 156.9 & - \\
\hline 10 & Tis-Abay-I & 1450.0 & - & 1787.0 & 1784.0 & 32273.0 & 9126.0 & - & - \\
\hline 11 & Tis-Abay-II & 1450.0 & - & 1787.0 & 1784.0 & 32273.0 & 9126.0 & - & - \\
\hline 12 & Genale Dawa-3 & 765.0 & 1685.0 & 1120.0 & 1080.0 & 2570.0 & 2310.0 & 98.0 & 20 \\
\hline 13 & GERD & - & 1615.0 & 640.0 & 590.0 & 74000.0 & 59200.0 & 1561.0 & - \\
\hline 14 & Koysha & - & - & 179.0 & - & 6000.0 & - & - & - \\
\hline 15 & TAMS & - & - & 756.0 & 625.0 & 8471.0 & 7410.0 & - & - \\
\hline 16 & Baro-1 & 1839.0 & 1546.0 & 1505.0 & 1485.0 & 800.0 & 480.0 & - & - \\
\hline 17 & Baro-2 & 1839.0 & 1546.0 & 1320.0 & 1318.0 & 60.0 & 20.0 & - & - \\
\hline 18 & Geba I & - & - & 2180.0 & 2160.0 & 1470.0 & 1392.0 & 115.0 & - \\
\hline 19 & Geba II & - & - & 1700.0 & 1698.0 & 38.0 & 8.0 & 1.8 & - \\
\hline 20 & Genale Dawa-6 & 440.0 & 2040.0 & 585.0 & 580.0 & 181.0 & 39.3 & 8.0 & 12 \\
\hline 21 & Hallele Werabesa I & - & - & 1565.0 & 1525.0 & 3228.0 & - & 210.0 & 70 \\
\hline 22 & Hallele Werabesa II & - & - & 1485.0 & 1470.0 & 1018.0 & - & 40.0 & 25 \\
\hline 23 & Gojeb & 1755.0 & 1585.0 & 1150.0 & 1105.0 & 2476.0 & 1602.0 & 48.6 & - \\
\hline 24 & Chemoga Yeda & - & - & - & - & - & - & - & - \\
\hline 25 & Beko-Abo & - & - & 1062.0 & 1010.0 & 31700.0 & 17475.0 & 403.0 & 150 \\
\hline 26 & Karadobi & - & - & 1146.0 & 1100.0 & 40200.0 & 17.0 & 445.0 & 150 \\
\hline 27 & Wabeshebele- 18 & - & 2362.0 & 580.0 & 555.0 & 4000.0 & 2000.0 & 83.0 & - \\
\hline 28 & Beshilo & - & - & 1390.0 & 190.0 & 12700.0 & - & - & - \\
\hline 29 & Tekeze-2 & - & - & - & - & - & - & - & - \\
\hline 30 & Gibe- 4 & - & - & - & - & 10000.0 & - & - & - \\
\hline 31 & Gibe 5 & - & - & - & - & - & - & - & - \\
\hline 32 & Upper Dabus & - & - & 1378.0 & 1358.0 & 2660.0 & 2639.0 & - & - \\
\hline 33 & Lower Dedessa & - & - & 1040.0 & 900.0 & - & 3500.0 & 64.0 & - \\
\hline 34 & Lower Dabus & - & - & - & - & - & - & - & - \\
\hline 35 & Birbir A & - & - & 1434.0 & 1402.0 & 1615.7 & 1546.0 & - & - \\
\hline \multirow[t]{3}{*}{36} & Birbir-R & - & - & 1140.0 & 1059.0 & 1940.0 & 1740.0 & - & - \\
\hline & Number of Data & 10 & 7 & 31 & 30 & 31 & 26 & 22 & 8 \\
\hline & Data Availability & $27 \%$ & $19 \%$ & $84 \%$ & $81 \%$ & $84 \%$ & $70 \%$ & $59 \%$ & $22 \%$ \\
\hline
\end{tabular}


was available. They arrived at the coefficients by statistical regression analysis of the GRanD database. Equation (3) was more accurate with $\mathrm{R}^{2}=0.92$ vs $\mathrm{R}^{2}=0.80$ for Equation (4). In this research these equations were reversed to calculate the reservoir area wherever possible.

\subsection{Water Consumption by Multipurpose Reservoirs}

This study includes reservoir where irrigation is the most dominating water use (e.g. Koka, Amerti Neshe, Fincha, Gilgel Gibe I, Gibe III, Melkawakena, and Tana Beles), and also a large natural lake where hydropower is just a minor add-on (e.g. Tis Abay I and II). For such reservoirs, high water consumption estimates will be obtained, as all the evaporation losses are ascribed to the hydropower production. Compared to reservoirs solely built for hydropower production, multipurpose reservoirs are expected to be more water intensive, which is not surprising given that the hydropower is not the primary design focus in such cases. It is vital to see the effect of multipurpose reservoir in defining what proportion of the water consumed by the reservoir is allocated for hydropower. This is because a distinct volume of water used for hydropower can also be used for other purposes (e.g., a given volume of discharged water can be used for hydropower generation and irrigation). The explicit prioritizing of services is challenging since priorities can change over time and are unique to each dam in the country. Thus, an allocation method that treats all multipurpose dams on a consistent basis is required.

In this research, as adopted by [27], allocation factors based on economic benefits were used, as it facilitated evaluating the relative benefits of employed purposes in terms of monetized values. The study acknowledges that the economic benefits for each purpose can vary over time; however, using economic benefit for allocation of water consumption provides a consistent basis for all large number of hydropower dams in Ethiopia.

The contribution of irrigation to agricultural GDP and total national GDP is estimated as $5.7 \%$ and $2.5 \%$ during the $2005 / 06$ cropping season [28]. This shows that the contribution of irrigation to national income is very small compared to the $28 \%$ contribution of crop production. Reference [28] has also predicted this contribution under conservative estimates as $9 \%$ and $3.7 \%$ to agricultural GDP and overall GDP, respectively.

In 2004, the share of the manufacturing sector in the GDP was $4.2 \%$. Even at the end of 2009 the share of the manufacturing sector for the GDP stood at a mere $4 \%$. Value added in the manufacturing sector grew during the first phase of (growth and transformation plan) GTP I at a rate of 14.6\% pushing its share in the GDP to $4.8 \%$. The GTP II plan has a target of an average growth rate of $20 \%$ per annum of an industrial output over the five-year plan period and increase the static share of the industrial sector in the GDP from $15.1 \%$ in 2015 to $22.3 \%$ in 2020. In particular, the manufacturing sector is expected to grow annually at a rate of $21.9 \%$ over the five-year period [29]. Reference [29] has shown the share 
of the large and medium manufacturing industry in GDP growth to be between 2\% in 2005 and 8\% in 1998. The average over 20 years (between 1996 and 2015) is about $3.7 \%$. It is wise to note here that, this $3.7 \%$ is only for large and medium scale manufacturing industries. Such industries are assumed in this research to directly use the energy supply by Ethiopian Electric Power. From the total energy consumed in Ethiopia 3\% is by industry [30], besides, the contribution of industry to the national economy is $21.6 \%$. Though hydropower contributes to $90 \%$ of the power production, its contribution to total energy production is estimated to be $88 \%$, which makes the hydropower contribution to the GDP to be about $3.26 \%$.

The ratio of Hydropower to Irrigation contribution to the national economic growth (here measured using their impact on GDP) would be 3.7:3.26. Thus, the water consumption share of hydropower for a multipurpose reservoir would roughly be $3.26 /(3.7+3.26)=46.8 \%$.

\section{Result and Discussion}

Reservoirs have been perceived as suppliers of water rather than consumers. Besides, Ethiopia's water management policy takes water allocation as the core issue for demand management. Given the large number of planned hydropower projects in the country and the corresponding large quantities of water involved, the effect of such allocation driven demand management policy shall be scrutinized. In attempting to understand the effect of water resources management policy on hydropower development, this study aims at evaluating the water consumption by all existing, under construction and planned storage regulated hydropower plants in Ethiopia and describe the impact on its production. Thus, this research will estimate the water consumed by storage regulated hydropower developments on the basis of the available data and information. The outputs from such analysis are then basically the annual water consumption by built, under construction and planned storage regulated hydropower projects. It is evident that the results' accuracy will vary depending on preceding levels of knowledge about the reservoir operation of the hydropower project.

\subsection{Evaporation Loss}

From the methodology discussed above, what is required to calculate the evaporation from each dam are the coordinates (for the ETo) and the surface area. As shown in Figure 2 the annual ETo value computed ranges between 2350 $\mathrm{mm}$ /year nearby Dallol Depression and $661 \mathrm{~mm}$ /year around the high lands of the country. This map conspicuously displays the annual reservoir evaporation, if a reservoir is built at a location.

\subsection{Water Consumption by Hydropower Projects}

In this study empirical equations suggested by Reference [26] were reversed to calculate the reservoir area wherever Equation (3) is adopted. The results of 
these computations can be seen from Table 3 .

As shown in Table 3 still there are projects (Lower Dabus, Gibe 5, Tekeze 2 and Chemoga Yeda), which haven't yet been estimated due to lack of information needed to estimate the surface area. Nonetheless, the maximum annual water consumed by the existing projects in Ethiopia is in the tune of $1.766 \mathrm{BMC}$ from which, $0.980 \mathrm{BCM}$ is attributed to hydropower production. However, this assumes that all dams are filled to capacity, which is clearly not the case. The maximum evaporation assumes that all dams operate at the design capacity, and therefore, the surface area of the water body within each reservoir is assumed to be filled to the design capacity. This assumption may not be valid, because dams often operate at a capacity less than the design capacity. Unfortunately, statistics regarding actual capacity and yearly capacity reduction due to sedimentation are not available for all dams. Therefore, a reliable methodology for determining the overestimated evapotranspiration was not possible for each reservoir. Due to lack of data on real time operation of the reservoir (rule curves) the analysis, in this study case, was made on the basis of annual evaporation. Most studies conducted earlier assume that all dams are half-full. Since the surface area of a dam correlate with its capacities, this study reduced this full capacity number by $50 \%$ as recommended by [26]. It is assumed in this study that the entire surface area of the reservoirs (except those plants that use Lake Tana as their reservoir) is anthropogenic, but that is not true. Rivers do have a surface area, and in some cases the surface area is not insubstantial. An additional 10\% reduction [26] was administered in order to account for the fact that rivers had also some evaporative loss before the dam was constructed. Therefore,

\section{Expected Evaporation $=0.4 \times$ Maximum Evaporation}

Accordingly, the expected annual water consumption by the indicated reservoirs in Ethiopia would be in the range of 0.706 and $1.766 \mathrm{BCM}$, from which the hydropower production stake is between 0.392 and $0.980 \mathrm{BMC}$.

The water consumption share by hydropower generation for the "under-construction" schemes will be between 1.489 and 3.722 BMC per year. From these projects GERD is solely constructed for hydropower development while the other two (Genale Dawa 3 and Koysha) include irrigation as their other purpose use.

All other upcoming planned projects, hydropower production water consumption share will be between 1.876 to $4.686 \mathrm{BMC} /$ year. Among these projects only those in Abay Basin (Karadobi, Beshilo, Lower Dabus, Upper Dabus, Lower Didessa and Chemoga-Yeda) are expected to heavily involve in power production than other multipurpose projects. In future, the total planned and existing projects hydropower production will take a maximum water consumption of 9.389 BMC/year with expected value of $3.756 \mathrm{BMC} /$ year. It can be argued that hydropower is a by-product of reservoir construction and deserves no allocation or alternatively that the hydropower generation should receive the entire water consumption burden. However, this result shows allocation of water to other 
Table 3. Estimated annual rainfall, evaporation and surface area.

\begin{tabular}{|c|c|c|c|c|c|c|c|}
\hline \multirow{2}{*}{ No. } & \multirow{2}{*}{ Name } & \multirow{2}{*}{$\begin{array}{c}\text { Evaporation } \\
\mathrm{mm} / \mathrm{yr}\end{array}$} & \multirow{2}{*}{$\begin{array}{l}\text { Area } \\
\mathrm{Km}^{2}\end{array}$} & \multicolumn{2}{|c|}{ Evaporation $\left(10^{9} \mathrm{~m}^{3}\right)$} & \multicolumn{2}{|c|}{ HP contribution Evaporation $\left(10^{9} \mathrm{~m}^{3}\right)$} \\
\hline & & & & Maximum & Expected & Maximum & Expected \\
\hline \multicolumn{8}{|c|}{ Operational } \\
\hline 1 & Aba Samuel & 1564.72 & $6.176^{1}$ & 0.01 & 0.004 & 0.005 & 0.002 \\
\hline 2 & Amerti Neshe & 1493.971 & 22.8 & 0.034 & 0.014 & 0.016 & 0.007 \\
\hline 3 & Fincha & 1497.209 & 345 & 0.517 & 0.207 & 0.242 & 0.097 \\
\hline 4 & Gibe-III & 2015.988 & 200 & 0.403 & 0.161 & 0.189 & 0.075 \\
\hline 5 & Gilgel Gibe I & 1685.076 & 51.06 & 0.086 & 0.034 & 0.040 & 0.016 \\
\hline 6 & Koka & 1740.216 & 177 & 0.308 & 0.123 & 0.144 & 0.058 \\
\hline 7 & Melkawakena & 1459.513 & 81.5 & 0.119 & 0.048 & 0.056 & 0.022 \\
\hline 8 & Tana Beles & 1683.879 & 3120 & $5.254^{*}$ & $2.101^{*}$ & 0 & 0 \\
\hline 9 & Tekeze-1 & 1840.604 & 156.88 & 0.289 & 0.115 & 0.289 & 0.115 \\
\hline 10 & Tis-Abay-I & 1683.879 & 3120 & $5.254^{*}$ & $2.101^{*}$ & 0 & 0 \\
\hline 11 & Tis-Abay-II & 1683.879 & 3120 & $5.254^{*}$ & $2.101^{*}$ & 0 & 0 \\
\hline \multicolumn{4}{|c|}{ Total Operational } & $1.766^{*}$ & $0.706^{*}$ & $0.980^{*}$ & $0.392^{*}$ \\
\hline \multicolumn{8}{|c|}{ Under Construction } \\
\hline 1 & Genale Dawa-3 & 1817.498 & 98 & 0.178 & 0.071 & 0.083 & 0.033 \\
\hline 2 & GERD & 2151.941 & 1561 & 3.359 & 1.344 & 3.359 & 1.344 \\
\hline 3 & Koysha & 2082.768 & 286.882 & 0.598 & 0.239 & 0.280 & 0.112 \\
\hline \multicolumn{4}{|c|}{ Total Under Construction } & 4.134 & 1.654 & 3.722 & 1.489 \\
\hline \multicolumn{8}{|c|}{ Feasibility } \\
\hline 1 & TAMS & 2164.46 & $203.04^{1}$ & 0.439 & 0.176 & 0.205 & 0.082 \\
\hline 2 & Baro-1 & 1752.508 & $103.12^{1}$ & 0.181 & 0.072 & 0.085 & 0.034 \\
\hline 3 & Baro-2 & 1841.879 & $6.23^{1}$ & 0.011 & 0.005 & 0.005 & 0.002 \\
\hline 4 & Geba I & 1685.962 & 115 & 0.194 & 0.078 & 0.091 & 0.037 \\
\hline 5 & Geba II & 1821.454 & 1.8 & 0.003 & 0.001 & 0.001 & 0.000 \\
\hline 6 & Genale Dawa-6 & 2092.875 & 8 & 0.017 & 0.007 & 0.008 & 0.003 \\
\hline 7 & Hallele Werabesa I & 1765.207 & 210 & 0.371 & 0.148 & 0.174 & 0.069 \\
\hline 8 & Hallele Werabesa II & 1783.507 & 40 & 0.071 & 0.029 & 0.033 & 0.014 \\
\hline 9 & Gojeb & 1874.398 & 48.578 & 0.091 & 0.036 & 0.043 & 0.017 \\
\hline 10 & Chemoga-Yada & 1391.495 & - & - & - & - & - \\
\hline \multicolumn{4}{|c|}{ Total Feasibility } & 1.379 & 0.551 & 0.645 & 0.258 \\
\hline
\end{tabular}




\section{Continued}

\begin{tabular}{|c|c|c|c|c|c|c|c|}
\hline \multicolumn{8}{|c|}{ Other Planned (Pre-Feasibility, Reconnaissance, Identification) } \\
\hline 1 & Beko-Abo & 2105.173 & 403 & 0.848 & 0.339 & 0.397 & 0.159 \\
\hline 2 & Karadobi & 1918.796 & 445 & 0.854 & 0.342 & 0.854 & 0.342 \\
\hline 3 & Wabishebele- 18 & 2135.442 & 83 & 0.177 & 0.071 & 0.083 & 0.033 \\
\hline 4 & Beshilo & 1882.471 & $627.63^{2}$ & 1.181 & 0.473 & 1.181 & 0.473 \\
\hline 5 & Tekeze-2 & 2002.924 & - & - & - & - & - \\
\hline 6 & Gibe-4 & 2106.143 & $489.02^{2}$ & 1.03 & 0.412 & 0.482 & 0.193 \\
\hline 7 & Gibe 5 & 2169.374 & - & - & - & - & - \\
\hline 8 & Upper Dabus & 1867.205 & $379.09^{2}$ & 0.708 & 0.283 & 0.708 & 0.283 \\
\hline 9 & Lower Dedessa & 1982.835 & 64 & 0.127 & 0.051 & 0.127 & 0.051 \\
\hline 10 & Lower Dabus & 1867.205 & - & - & - & - & - \\
\hline 11 & Birbir A & 1954.78 & $138.04^{1}$ & 0.27 & 0.108 & 0.126 & 0.051 \\
\hline 12 & Birbir-R & 2013.038 & $88.257^{2}$ & 0.178 & 0.071 & 0.083 & 0.033 \\
\hline \multicolumn{4}{|c|}{$\begin{array}{l}\text { Total Other Planned (Pre-Feasibility, } \\
\text { Reconnaissance, Identification) }\end{array}$} & 5.373 & 2.149 & 4.041 & 1.617 \\
\hline
\end{tabular}

${ }^{1}$ Estimated on the basis of Equation (3); ${ }^{2}$ Estimated on the basis of Equation (4); * The evaporation from the natural reservoirs like Lake Tana were NOT considered to be part of hydropower consumption (Tana Beles, Tis Abay I and Tis Abay II).

purposes is subjective and highly influences interpretations of water consumption.

The total water consumption of the hydropower in Ethiopia as percentage of the stored water is between nearly $0.0 \%$ (in case of Tana Beles, Tis Abay I \& II, and GERD) and $10.64 \%$ (in case of Upper Dabus). The average water consumption as percentage of the total storage is $2.49 \%$ (Table 4). It is wise to note from Table 4 that the total artificial reservoir volume that will be created after completion of the projects is $233.131 \mathrm{BCM}$, which is by far greater than the surface water volume the country possesses. And the surface area of the whole artificial reservoirs will cover $6439.095 \mathrm{Km}^{2}$. It is highly likely that the design stage of the planned projects either decrease the size of the reservoir and/or extend the reservoir filling time which ultimately alters the estimated evaporations. This again indicates that the future water consumption by the hydropower plants shall be revised in accordance with changes made in the final design of each planned projects.

\subsection{Water Allocation for Hydropower}

The Ethiopian water resources management policy (WRMP) was prepared on the basis of Proclamation No.197/2000 [31], which is the basic legal instrument governing the management, planning, utilization and protection of water resources in Ethiopia. This policy is prepared by the federal Ministry of water, 
Table 4. Water consumption as a fraction of the total reservoir capacity.

\begin{tabular}{|c|c|c|c|c|c|c|c|c|c|}
\hline No. & Name & $\begin{array}{l}\text { Consumption } \\
\text { (BCM) }\end{array}$ & $\begin{array}{l}\text { Capacity } \\
\text { (BCM) }\end{array}$ & $\begin{array}{c}\text { Consumption } \\
(\%)\end{array}$ & No. & Name & $\begin{array}{l}\text { Consumption } \\
\text { (BCM) }\end{array}$ & $\begin{array}{l}\text { Capacity } \\
\text { (BCM) }\end{array}$ & $\begin{array}{c}\text { Consumption } \\
(\%)\end{array}$ \\
\hline 1 & Aba Samuel & 0.002 & 0.065 & 2.88 & 17 & Baro-2 & 0.002 & 0.06 & 3.90 \\
\hline 2 & Amerti Neshe & 0.007 & 0.106 & 6.18 & 18 & Geba I & 0.037 & 1.47 & 2.48 \\
\hline 3 & Fincha & 0.097 & 1.121 & 8.64 & 19 & Geba II & 0.000 & 0.038 & 1.23 \\
\hline 4 & Gibe-III & 0.075 & 14.7 & 0.51 & 20 & Genale D.-6 & 0.003 & 0.181 & 1.81 \\
\hline 5 & Gilgel Gibe I & 0.016 & 0.84 & 1.89 & 21 & Hallele W. I & 0.069 & 3.228 & 2.15 \\
\hline 6 & Koka & 0.058 & 1.186 & 4.85 & 22 & Hallele W. II & 0.014 & 1.018 & 1.33 \\
\hline 7 & Melkawakena & 0.022 & 0.693 & 3.24 & 23 & Gojeb & 0.017 & 2.476 & 0.68 \\
\hline 8 & Tana Beles & 0.000 & 32.273 & 0.00 & 24 & Beko-Abo & 0.159 & 31.7 & 0.50 \\
\hline 9 & Tekeze-1 & 0.115 & 9.293 & 1.24 & 25 & Karadobi & 0.342 & 40.2 & 0.85 \\
\hline 10 & Tis-Abay-I & 0.000 & 32.273 & 0.00 & 26 & Wabeshebele -18 & 0.033 & 4 & 0.83 \\
\hline 11 & Tis-Abay-II & 0.000 & 32.273 & 0.00 & 27 & Beshilo & 0.473 & 12.7 & 3.72 \\
\hline 12 & Genale D.-3 & 0.033 & 2.57 & 1.29 & 28 & Gibe- 4 & 0.193 & 10 & 1.93 \\
\hline 13 & GERD & 1.344 & 74000 & 0.00 & 29 & Upper Dabus & 0.283 & 2.66 & 10.64 \\
\hline 14 & Koysha & 0.112 & 6 & 1.86 & 30 & Birbir A & 0.051 & 1.616 & 3.13 \\
\hline 15 & TAMS & 0.082 & 8.471 & 0.97 & 31 & Birbir-R & 0.033 & 1.94 & 1.71 \\
\hline 16 & Baro-1 & 0.034 & 0.8 & 4.21 & \multicolumn{4}{|c|}{ Average } & 2.41 \\
\hline
\end{tabular}

irrigation and Energy and ratified by the policy making organs. The main objective of water management policy is to maximize the utilization of the available water, minimize water losses, conserve water resources and promote effective water use efficiency. The issue of water consumption and demand is indirectly addressed in the objective of WRMP of the country which states "...allocation and appointment of water based on comprehensive and integrated plans and optimum allocation principles that incorporate efficiency of use, equity of access and sustainability of resource". Accordingly, demands can't be addressed without prior allocation of water and consumption shall strictly follow "efficient means of use".

The existing WRMP policy addresses the management of water demands in sectors, including municipal, livestock, industry, irrigation, hydropower, tourism, inland water transport, aquatic resources and environmental flows. According to the priorities stated in the National Water Strategy, water for municipal purposes is a top priority among all sectors, followed by any of the sector having larger national economic importance. Moreover, the policy emphasized adherence to the principles of Integrated Water Resources Management (IWRM), which is a holistic approach to water resources development and management. The proclamation covers most of the issues that need to be addressed in IWRM.

Agriculture is by far the main water-withdrawing sector in Ethiopia. Based on 
the total irrigated area, cropping pattern and calendar, annual agricultural water withdrawal in 2016 was estimated at around 9 billion $\mathrm{m}^{3}$ while the livestock, Municipalities and industries have withdrawn $0.687,0.81$ and 0.051 billion $\mathrm{m}^{3}$, respectively [32]. This study has confirmed that hydropower has been consuming water as small as 0.392 billion $\mathrm{m}^{3}$ per year and this consumption will become 1.881 billion $\mathrm{m}^{3}$ when the under-construction schemes are completed, upon which hydropower becomes the second most water consuming. Which need attention while allocating water for every water resource development project.

The unallocated water for hydropower consumption will finally reveal itself either as environmental, social or monetary costs. The water that used to flow downstream to adequately support the ecosystem will not get secured by which degraded environmental performance may exist. Unbalanced water use and demand satisfaction will prevail, if the intended allocation doesn't work out, for which banning some types of uses places the risk disproportionally on certain groups of users. Besides, such water loss from the reservoir also will manifest itself on the overall power production of the project. In countries like Ethiopia, wherein larger reservoir regulated hydropower projects are planned and/or operated, and the water resources management policy strictly bases itself on water allocation, hydropower development shall be due candidate and deserves water allocation.

\section{Conclusions}

This paper raises a poignant reminder of Ethiopia's water resources management, under the existing Water Resources Management Policy (WRMP) proclamation no.197/200, which underscores allocation-based management of water resources. Presently, a total of 1.881 billion $\mathrm{m}^{3}$ of water is consumed by single (hydropower) and multi (hydropower+) purpose reservoir regulated projects. But given that the planned energy generation target is to rely on $86 \%$ hydropower by 2020 , a situation that will extend further the $88 \%$ dependency on the sector for power needs, there is an urgent need to look keenly on water resource allocation for sustainability. Using different auditing methods including evaporation estimation, this research has underscored the importance of the enforcement of the present WRMP in Ethiopia to realize the integrated water resource management goals.

Even though the definition of water consumption does not exclude other loss terms from being part of the water loss, it appears from the reviewed publications that the dominating term for water losses is evaporation losses from the reservoir surface.

The future total reservoir regulated hydropower development water consumption is 3.756 billion $\mathrm{m}^{3}$ per year. This value is nearly $3 \%$ of the total annual surface water flow the country possesses. The results also show that hydropower consumption in the country will take an average of $2.41 \%$ of the total water stored in a reservoir. This figure is in the range of nearly zero to $10.64 \%$. Most of 
these reservoir-regulated hydropower projects are studied and designed as a multi-purpose project in which irrigation is the only other purpose besides the hydropower projects considered in this study. Other purpose water consumptions (fishery, flood control, recreation, etc.) were not considered. The ratio of the water consumption is estimated on the basis of the national gross domestic product contribution of two of the multipurpose viz. irrigation and large and medium scale manufacturing industries. Thus, the above results shall be interpreted cautiously.

The total reservoir volume that will be created in the country after completion of the 22 (10 Feasibility and 12 Pre-feasibility, reconnaissance and identification stage) planned projects is larger than $233 \mathrm{BCM}$, which is by far greater than the surface water volume the country possesses. This again indicates that the future water consumption by hydropower plants shall be revised in accordance with changes made in the final design of each planned project. Besides, future demand and consumption analysis and interpretations shall also focus on the other multipurpose sector of the water resource development.

All the estimations made in this research are on the basis of average year analysis. Dry and wet years will bring about different results; thus, the results shall be revised for such wetting pattern of the country. Besides, the methodology adopted in estimating the reservoir characters that determine water consumption lacks detail information on reservoir rule curves and real time operation curves. This data/information was obtained using empirical equations which warrants such data should be collected in future and revises the result obtained in this research.

Agriculture is by far the main water-withdrawing sector in Ethiopia. Based on the total irrigated area, cropping pattern and calendar, annual agricultural water withdrawal in 2016 was estimated at around 9 Billion $\mathrm{m}^{3}$ while the livestock, Municipalities and industries have withdrawn $0.687,0.81$ and 0.051 Billion $\mathrm{m}^{3}$, respectively. This study has confirmed that hydropower has been consuming water as small as 0.392 Billion $\mathrm{m}^{3}$ and this consumption will become 1.881 Billion $\mathrm{m}^{3}$ when the under-construction schemes are completed, upon which hydropower becomes the second most water consuming. The situation will get worse for the very reason of climate change effects. With all its assumptions and empirical equations adopted in this research, the study provides scientific support for the argument that the production of hydroelectricity, in most of our reservoir regulated hydropower schemes cases, is a water consumer. The unallocated water for hydropower consumption will finally reveal itself either as environmental, social or monetary costs. Besides, such water loss from the reservoir also will manifest itself on the overall power production of the project. In countries like Ethiopia, wherein larger reservoir regulated hydropower projects are planned and/or operated, and the water resources management policy strictly bases itself on water allocation, hydropower development shall be due candidate and deserves water allocation. 


\section{Acknowledgements}

The author acknowledges Ethiopian Electric Power (EEP), Ministry of water, irrigation and energy (MoWIE) and Generation Integrated Rural Development Consultant (GIRDC) for their valuable input to the research.

\section{Conflicts of Interest}

The author declares no conflicts of interest regarding the publication of this paper.

\section{References}

[1] Ethiopian Electric Power (EEP) (2020). https://www.eep.com.et/en/power-generation/

[2] GTP II (2015) Growth and Transformation Plan II, FDRE Planning Commission.

[3] Gleick, P.H. (1992) Environmental Consequences of Hydroelectric Development: The Role of Facility Size and Type. Energy, 17, 735-747. https://doi.org/10.1016/0360-5442(92)90116-H

[4] Gleick, P.H. (1993) Water in Crisis, A Guide to the World's Freshwater Resources. Oxford University Press, New York.

[5] Shiklomanov, I.A. (2000) Appraisal and Assessment of World Water Resources. Water International, 25, 11-32. https://doi.org/10.1080/02508060008686794

[6] Torcellini, P.A., Long, N. and Judkoff, R. (2003) Consumptive Water Use for US Power Production. National Renewable Energy Laboratory Golden, CO.

https://doi.org/10.2172/15005918

[7] Pasqualetti, M. and Kelley, S. (2008) The Water Costs of Electricity in Arizona.

[8] Gerbens-Leenes, P.W., Hoekstra, A.Y. and Van der Meer, T.H. (2009) The Water Footprint of Energy from Biomass: A Quantitative Assessment and Consequences of an Increasing Share of Bio-Energy in Energy Supply. Ecological Economics, 68, 1052-1060. https://doi.org/10.1016/j.ecolecon.2008.07.013

[9] Herath, I., Deurer, M., Horne, D., Singh, R. and Clothier, B. (2011) The Water Footprint of Hydroelectricity: A Methodological Comparison from a Case Study in New Zealand. Journal of Cleaner Production, 19, 1582-1589. https://doi.org/10.1016/j.jclepro.2011.05.007

[10] Pfister, S., Saner, D. and Koehler, A. (2011) The Environmental Relevance of Water Consumption in Global Power Production. The International Journal of Life Cycle Assessment, 16, 580-591. https://doi.org/10.1007/s11367-011-0284-8

[11] Bakken, T.H., Killingtveit, Å., Engeland, K., Alfredsen, K. and Harby, A. (2013) Water Consumption from Hydropower Plants-Review of Published Estimates and an Assessment of the Concept. Hydrology and Earth System Sciences, 17, 3983-4000. https://doi.org/10.5194/hess-17-3983-2013

[12] CRGE (2011) FDRE, Ethiopia's Climate-Resilient Green Economy, Green Economy Strategy. https://www.undp.org/content/dam/ethiopia/docs/Ethiopia\%20CRGE.pdf

[13] Seyoum Hailu, S. (1998) Hydropower of Ethiopia: Status, Potential and Prospects. EACE (Ethiopian Association of Civil Engineers) Bulletin, 1, No. 1.

[14] JICA (2015) The Project for Formulating Master Plan Development of Geothermal Energy in Ethiopia. 
[15] MoWIE (2017) http://www.mowie.gov.et/dams-and-hydropower

[16] Aguilar, S., Louw, K. and Neville, K. (2011) IHA World Congress Bulletin, International Institute for Sustainable Development (IISD) and International Hydropower Association (IHA), Issue 1, Volume 139. http://www.iisd.ca/ymb/hydro/iha2011

[17] Hoekstra, A.Y., Chapagain, A.K., Aldaya, M.M. and Mekonnen, M.M. (2011) The Water Footprint Assessment Manual: Setting the Global Standard. Earthscan, London, UK.

[18] Mekonnen, M.M. and Hoekstra, A.Y. (2012) The Blue Water Footprint of Electricity from Hydropower. Hydrology and Earth System Sciences, 16, 179-187. https://doi.org/10.5194/hess-16-179-2012

[19] Yesuf, M.B. (2012) Impacts of Cascade Hydropower Plants on the Flow of the River System and Water Level in Lake Turkana in Omo-Ghibe Catchment, Ethiopia. Master's Thesis, Norwegian University of Science and Technology, Trondheim, Norway.

[20] Tefferi, M.E.A. (2012) The Effect of Ethiopian Hydropower Reservoirs on Blue Nile River Flow Regime. Master's Thesis, Norwegian University of Science and Technology, Trondheim, Norway.

[21] Demeke, T.A., Marence, M. and Mynett, A.E. (2013) Evaporation from Reservoirs and the Hydropower Water Footprint. In: Proceedings from Africa 2013, Addis Ababa, Ethiopia, 16-18 April 2013.

[22] Lenters, J.D., Kratz, T.K. and Bowser, C.J. (2005) Effects of Climate Variability on Lake Evaporation: Results from a Long-Term Energy Budget Study of Sparkling Lake, Northern Wisconsin, USA. Journal of Hydrology, 308, 168-195. https://doi.org/10.1016/j.jhydrol.2004.10.028

[23] Singh, V.P. and Xu, C.-Y. (1997) Evaluation and Generalization of 13 Mass-Transfer Equations for Determining Free Water Evaporation. Hydrological Processes, 11, 311-323. https://doi.org/10.1002/(SICI)1099-1085(19970315)11:3<311::AID-HYP446>3.0.CO ;2-Y

[24] Winter, T.C., Rosenberry, D.O. and Sturrock, A.M. (1995) Evaluation of 11 Equations for Determining Evaporation for a Small Lake in the North Central United States. Water Resources Research, 31, 983-993. https://doi.org/10.1029/94WR02537

[25] FAO (2000) Crop Evapotranspiration: Guidelines for Computing Crop Water Requirements. Irrigation and Drainage Paper 56. FAO, Rome.

[26] Amit, K. and Karen, F. (2015) FAO, AQUASTAT Program, Evaporation from Artificial Lakes and Reservoirs.

[27] Lee, U., Han, J., Elgowainy, A. and Wang, M. (2017) Regional Water Consumption for Hydro and Thermal Electricity Generation in the United States. Applied Energy, In Press. https://doi.org/10.1016/j.apenergy.2017.05.025

[28] Hagos, F., Makombe, G., Namara, R.E. and Awulachew, S.B. (2011) Importance of Irrigated Agriculture to the Ethiopian Economy: Capturing the Direct Net Benefits of Irrigation. https://doi.org/10.4314/ejdr.v32i1.68597

[29] UNDP (2016) Understanding African Experiences in Formulating and Implementing Plans for Emergence Growing Manufacturing Industry in Ethiopia.

[30] International Energy Agency (2014). http://www.iea.org/statistics/statisticssearch/report/?year=2014\&country=Ethiopia $\underline{\text { \&product }=\text { Balances }}$ 
[31] Proclamation No. 197/2000, FDRE, Ethiopian Water Resources Management Proclamation.

[32] FAO (2016) AQUASTAT Country Profile-Ethiopia. Food and Agriculture Organization of the United Nations (FAO), Rome, Italy. 